\title{
Automatic Detection of Large Rocks by Image Processing
}

by Hiroshi TAKAHASHI ${ }^{1}$ and Katsumi SANO $^{2}$

1. Dept. of Geoscience and Technology, Tohoku University, Aoba-ku, Sendai 980-77

2. Graduate School of Tohoku University

\begin{abstract}
This paper presents a detection method of large rocks in the rock pile using an image processing. In this study, the shadow of the large rock was used to distinguish the large rocks from the background. Therefore, in order to change the location of shadow of the large rocks, 4 light sources were set around the CCD camera and 4 images were obtained with changing the light sources. The thresholding was carried out for these images, and the common area of these images was obtained because the location of the large rocks was not changed even if the light sources were changed. Then, some large rocks were detected by the area analysis and shape factor analysis. However, some other large rocks were still remained in the image. Therefore, then the shrinking procedure was made for this image. After this procedure, the shape factor analysis was carried out again to detect the remaining large rocks. It was confirmed that this procedure works well to detect the large rocks in the rock pile.
\end{abstract}

KEY WORDS : Image Processing, Thresholding, Detection of Large Rocks

\section{1.はじめに}

石灰石は，日本国内で自給可能な貴重な鉱物資源であり，現在， 数多くの石灰石鉱山が採掘を行っている。これらの現場のほとん どは，図１に示すように切羽で採掘した鉱石を立坑に投入し，鉱 石をクラッシャに導いた後に粉砕し，さらに所定のサイズに分級 するシステムを採用している。しかし大岩がクラッシャに入ると クラッシャを破壊する恐れがあるため, クラッシャ上にグリズリー バーと呼ばれる鉄格子を設置して大岩を受けとめ, 図 1 に示す 「小割室」と呼ばれる小さな部屋で岩石を砕く作業，いわゆる 「小割作業」を行っている。しかしながら，この小割室には粉塵 が大量に舞うなど，作業員にとって決して良好な作業環境とはい えないことから，一部の鉱山では小割室にブレーカおよびカメラ を設置し，カメラからの映像を基にブレーカを遠隔操作している ところもある。現在のこの方法は，オペレータが良好な環境で作 業ができるという利点をもたらしているが，一方，熟練と長時間 の連続した作業がオペレー夕に要求されるため, 大岩の小割作業 の自動化が求められている。

この大岩の小割作業は，石灰石鉱山のみならず，採石現場ある いはトンネル掘削現場などでも必要とされる技術である。これら の現場では，一般に発破で起砕された多数の岩石の山（以下，ず り山と記す）をホイールローダなどでトラックに積み込み，坑外

* 1996 年 7 月 10 日受付 12 月 20 日受理

1. 正会員 工博 東北大学助教授 工学研究科地球工学専攻

2. 東北大学大学院 工学研究科地球工学専攻

〔著者連絡先〕 FAX 022-217-7395 (東北大·地球)

キーワード：画像処理，2 值化，大岩検出
に排出しているが，起砕されたずり山中に大岩が存在すると，八 ンドリングが困難になり，作業効率が低下することから，ずり山 中の大岩をブレーカで破砕しているのが現状である。

さて, 小割作業を自動化するための一手段としてロボットの導 入が考えられる。製造業の分野では既にさまざまなロボットが導 入され, 多くの実績を挙げている。しかし, 一定のパターンの繰 り返し作業の多い製造業のロボットとは異なり, 小割作業の現場 に導入されるロボットにはより高度な機能が要求される。すなわ ち, 対象物である大岩の位置は常に一定ではなく, かつ大きさお よび形状も不定であることから，これらのロボットには自ら対象 物を含む周囲の環境を認識・判断し, 作業を実行する機能を具備 する必要がある。この機能の実現のためには, ロボットに視覚を 持たせることが必要不可欠であり, 著者らはこの視覚に対する画 像の適用について検討してきた1)-4)。画像の適用を考えている 理由は, 例えば CCD カメラなどを用いて撮影された画像は比較

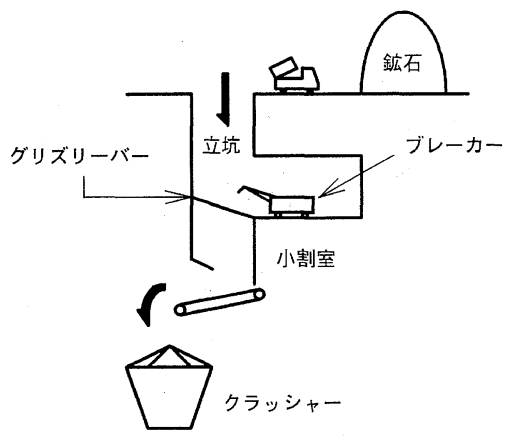

図 1 石灰石鉱山に扔ける鉱石破砝システムの概要 


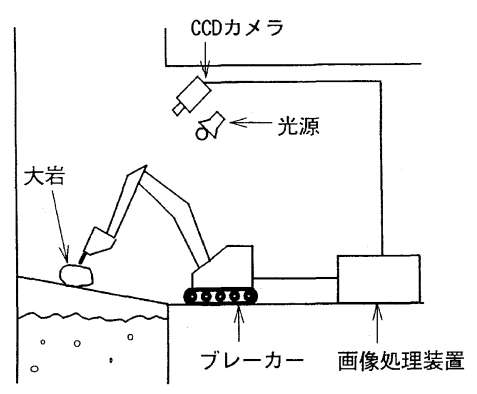

図 2 本研究で想定する大岩破砕システム
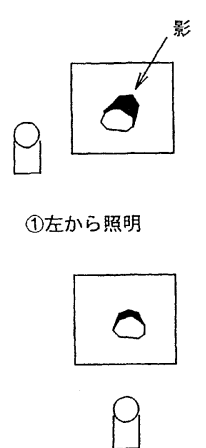

(3)上から照明

図 34 個の光源の設置状況

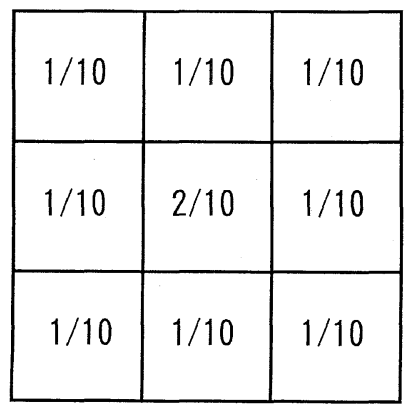

図 4 重み付き 8 近傍フィルタ
的広範囲の情報を含み，かつ目的に応じた処理が可能なためであ る。しかし, 岩石は形状が複雑であることから, 例えば背景が白 一色などの単純な環境に打ける単一岩石に対しては, 比較的簡単 に認識可能であるが5)，ずり山中における大岩を認識するには， 複雑な背景と大岩を自動的に区別する必要がある。中山ら ${ }^{6) 7}$ は, 発破で起砕された堆積物の大きさの分布を画像処理法を用いて推 定する方法を提案しているが，画像上に扔ける大岩の位置の検出 まで含めた画像処理法の検討はほとんど行われてなく, どのよう な処理法が有効であるかは明らかではない。

したがって, 本研究では, 画像により多数の岩石中における大 岩を検出するための画像処理法について検討することを目的とし ている。

\section{2. 大岩検出システムの概要}

図 2 に想定されるシステム全体の概念図を示した。本システム では, 小割室に設置したカメラからの情報を解析して大岩を自動 的に検出し, 検出された大岩の位置をブレーカに伝え, さらにブ レーカの先端を検出された大岩の重心位置に移動させ，自動的に 大岩の破砕作業を実行するものである。なお, 本研究では画像に よる大岩の検出のみを扱い, ブレーカの操作アルゴリズム等につ いては次報で検討する。

\section{$2 \cdot 1$ 撮影}

いずれの画像処理についてもいえることであるが，画像から目 的とする情報を抽出する際の結果の良否は, 撮影された原画像に 依存する部分が大きい。すなわち, 照明等を工夫し, 情報を抽出 しやすいような画像をまず画像処理装置に入力することが必要で ある。本研究では大岩の領域を検出し, 画像上の重心位置を求め ることが目的であるため, 大岩の領域と背景とを分離しなければ ならず，この分離がスムーズに行われるような画像が入力される ことが望ましい。

一般に, 領域はエッジ検出により抽出されることが多いが8), ほぼ同じ色彩の小さな多数の岩石で構成される背景から大岩の領 域を検出する場合には, 小さな多数の岩石による領域が大岩領域 と融合してしまい, かつ大岩のエッジのみが連続して検出される ことは極めて希である。そこで, 本研究では大岩による影の利用 を考える。すなわち, 影は光源と反対方向にでき, かつ影の領域 の画像強度は小さくなるが, 大岩の部分は光があたるため影の部 分に比べて画像強度が大きくなる。光源の位置を変えても大岩の 位置は変化しないが, 影は光源の位置の変化に従い変化する。し たがって, 光源の位置を変化させて数枚の画像を撮影し, それら の画像の共通領域を求めれば，その部分が大岩に相当する確率が 高い。それゆえ, 本研究では光源をカメラの上下左右 4 か所に設
置し, 1 個ずつ光源を点灯させて 4 通りの照明を行い, 図 3 に模 式的に示すような影のつけ方を変えた 4 枚の画像を撮影し, これ らを合成して影により大岩を背景から分離する。

\section{$2 \cdot 2$ 画像処理}

画像から物体の輪郭情報を抽出する処理法の 1 つにエッジ検出 がある。背景と物体の輝度差が比較的大きく, 簡単な形状の物体 の輪郭抽出には有効な手段であるが, 前述したように多数の岩石 中の大岩の検出では, 岩石自体の形状が複雑なこともあり，エッ ジ検出で大岩の輪郭情報を得ることは極めて難しいと考えられる。 そこで，ここでは 2 值画像を用いて大岩の検出を試み, エッジの 利用は今後の課題とする。

さて, 撮影した 4 枚の画像を 2 值化 ·合成して 1 枚の 2 値画像 を得るまでの処理について以下に述べる。最初に画像から雑音を 除去するために前処理として, 図 4 に示すような重み付き 8 近傍 フィル夕处理 ${ }^{9)}$ を行う。雑音除去後の画像に対して 2 值化処理を 行うが, この 2 值化処理を行う際の最も重要な点は, しきい值の 決定である。後述するように, サンプリングされた画像は画像処 理装置により $512 \times 512$ 画素に標本化されるが，ここでは，照明 の不均一性に対処するため, $32 \times 32$ 画素の正方形の領域により 画像領域全体を 256 か所に分割して場所ごとに 2 值化を行う。し きい值を高めに設定すると, 各領域の分割は確実に行われるが, 大岩の領域まで消滅する危険性が大きい。逆に低如設定すると, 大岩の領域は確実に残るが, 小岩石による領域の融合（領域が分 割されずに連結してしまう状態を，ここでは融合と呼ぶことにす る）の度合いが強く, 大岩の領域の検出が困難になる。本研究で は，2 值化のためのしきい值はその場所の輝度の平均值から算出 することにした。詳細については後述するが, 試行錯誤の結果, 輝度值の平均值が約 88 以下ではそれよりやや高いしきい值を, また輝度值の平均值が約 88 以上ではそれよりやや低いしきい值 を与えるようにすると, 最初の 2 值化の段階で大岩領域を残し, かつ小岩石の領域をある程度分割できることが分かった。それゆ え,ここでは次式を仮定した。

$$
a=\sqrt{88 \cdot m}
$$

ここに, $a$ はしきい值, $m$ は $32 \times 32$ 画素の領域における輝度值 の平均值である。ただし，(1)式中の 88 という值は岩石の表面反 射率に依存する。すなわち，同じ石灰岩でも採掘場所等が変わり， 岩質が変化すればそれに応じて変化する值であるが，これについ てはより多くの種類の岩石を用いて今後詳細に検討する必要があ る。

なお，使用した画像処理装置は黒い領域に対して処理を行うの で 2 值化後白黒反転を行い，石灰石を黒，影の部分を白とする。 大岩の影を使って大岩と小岩石を分離するため, 4 枚の画像の合 
成は，4 枚の画像中のすべての黒の共通領域だけを黒のまま残し， その他の部分は白とする。すなわち，4 枚の画像の論理積をとる。 そのため 4 枚中 1 枚でも影が写っていれば合成の結果，その部分 は白となる。

\section{$2 \cdot 3$ 大岩の検出}

画像中に生じる多数の領域は大きく分けて，1)大岩によるもの, 2)小岩石によるもの，および3)壁の 3 つに分けられる。そこで 本研究では各領域について面積, 重心座標, 形状係数を求め, こ れらを基に大岩の領域とそれ以外の領域とを区別する。最初に， 面積による処理を行う。ここでは 2 通りの岩石の堆積状態が考え られる。すなわち，小岩石がすべてグリズリーバーを通過して， 大岩のみがバーの上に存在する場合と, すべての岩石がグリズリー バー上に存在し，グリズリーバーを覆っている場合の 2 通りであ る。前者は破砕機の能力よりも鉱石の流れが少ない状態であり, 逆に後者は破砕機の能力よりも鉱石の流れが多い状態である。グ リズリーバーの 1 区画の大きさは既知であり，前者の場合，この 1 区画より小さい岩石はバーを通過し，バーの下部にあるが， 1 区画より大きい岩石は大岩としてバーの上に残ることになる。後 者の場合は，すべての岩石がグリズリーバー上に存在するが，こ れらの岩石は破砕工程が進むにつれて下方に移動し，やがて小岩 石はグリズリーバーを通過するが，大岩はバーに引っかかって， バーの上に残ることになる。したがって，1 区画の面積を基にし たしきい值を用いて面積の小さい領域を消去し, 消去されなかっ た領域を大岩と見なして検出する。ただし，カメラから遠い地点 ほどグリズリーバー 1 区画の大きさは小さくなるので, 図 5 に示 すように場所ごとに面積のしきい值を設定し，領域の重心位置に 応じた面積のしきい值を適用する。ただし, 図中の $\mathrm{y} は$ は,「画像 処理装置に取り込まれ, デジタル画像に変換された画像上の $\mathrm{y}$ 座標」を意味する。また，ここで「消去する」とは，その領域を 白くすることを意味する。また処理領域の分割数が 2 值化処理の 分割数に比べて少ないのは, 2 值化処理では多值画像を扱うのに 対して，この面積処理では 2 值画像を扱い，さらに面積処理では 岩石領域の面積を検討することになるため，個々の岩石全体の大 きさを考慮すると分割数はさほど多くなくても済むためである。 なお, 図 5 中の最小画素面積 $S_{\min }$ は, 後述する模型におけるグ リズリーバーの大きさを考慮し，本解析では 2,000 とした。次に 各領域の重心位置を求め, その重心位置より壁と考えられるもの を除外する。すなわち，カメラの位置は固定されているので，あ らかじめ予備実験を行い，左右の壁拧よび正面の壁に相当する部 分の画像上の領域を求めておき, 実際の画像処理により検出され た領域の重心位置がこの領域内に入った場合には，その領域は壁 と判断し, 除外する。なお, この際, 壁際に大岩が存在した場合, 同時に大岩も消去してしまう危険性があるが，これは上述のよう に4つの照明を用いて強制的に影を作ることで，ほとんど回避可

\begin{tabular}{|c|c|c|}
$y$ & $y=0$ \\
$y=150$ \\
Smin $* 1.3$ & $y=260$ \\
Smin $* 1.7$ & $y=370$ \\
Smin $* 2.3$ & $y=511$
\end{tabular}

Smin：最小画素面積
能である。

さて, 以上の処理を施した画像には, 小岩石の融合した領域拐 よびこれらの領域と大岩領域が融合した領域などが存在するため, これらを区別しなければならない。小岩石が融合してできた領域 は，形状の凹凸が大きいが，大岩の領域では形状の凹凸は小さい。 したがって，凹凸の程度により，まず区別が可能であると考えら れる。ここでは, 凹凸の程度を表す指標として形状係数を用い, これを基に明らかに大岩とみなせる領域を検出する。形状係数は 物体の形状の不規則さを示すものであり, ここでは次式で定義さ れる形状係数 ${ }^{10)}$ を用いた。

$$
K=\frac{4 \pi \times S}{L^{2}}
$$

ここに, $K$ は形状係数, $S$ は領域の面積, $L$ は周囲長である。す なわち, 各領域に対して形状係数 $K$ を計算し, 形状係数 $K$ が小 さいものを大岩として残し, 大きいものは多数の小岩石が融合し てできた領域と判断し, 消去する。なお, 判断の基準となる形状 係数のしきい值は, 試行錯誤により 6 とした。

この処理を終えた画像には, 大岩に小岩石が融合した領域およ び小岩石同士が融合してできた領域のうち前述の形状係数の処理 をクリアした領域が残っている。そこで, これらの領域に対し縮 退処理を行う。その結果, 図 6 に模式的に示すように小岩石同士 が融合した領域はいくつかの小領域に分離される。一方, 大岩と 小岩石が融合した領域は大岩の領域と小岩石による領域に分離さ れる。その後, 再び上述の面積処理に戻れば, 大岩領域のみが検 出され, 小岩石の領域は消去される。なお, 縮退を行うと画像中 のすべての領域が縮小されるので, 今までの処理に㧈ける最小画

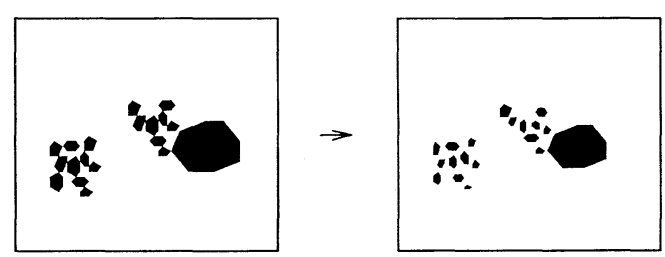

図 6 小岩石による領域の分割

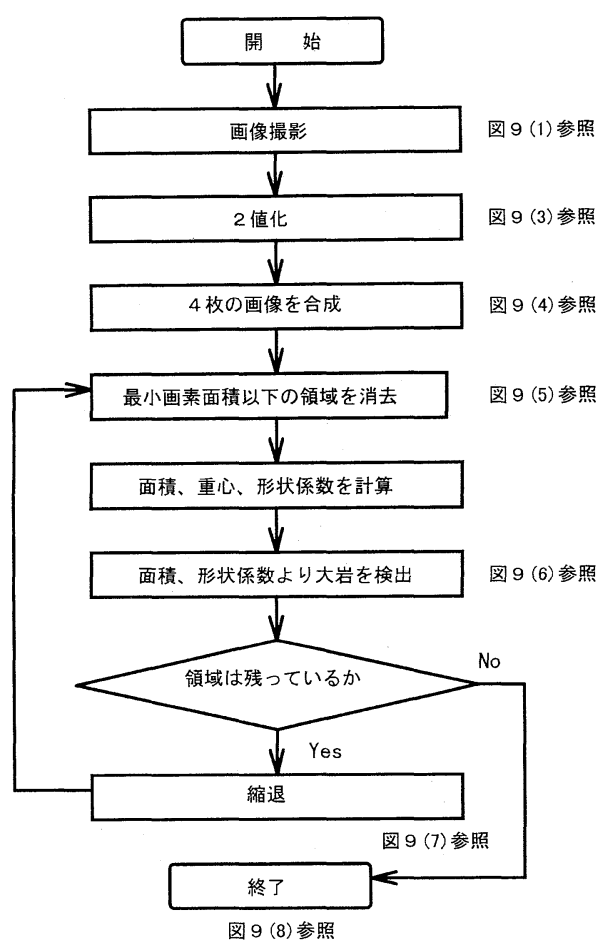

図 7 画像処理の流れ 
素面積をそのまま適用すると大岩領域も消去される可能性がある。 そこで縮退の度に最小画素面積を小さく設定し直す必要がある。 そのため, 本研究では次のような関数を考え, 縮退回数に応じて 最小画素面積を設定した。

$$
S_{\text {min }}^{\prime}=\frac{S_{\min }}{\sqrt[3]{N}}
$$

ここに, $S_{\min }^{\prime}$ は新しい最小画素面積, $S_{\min }$ は最初の最小画素面 積, $N$ は縮退回数である。

なお，画像処理の流れを図７に示した。

\section{3．実験装置および実験方法}

本実験に用いた実験装置の概略を図 8(a)に示した。実験装置 は大岩の破砕現場および小割室を模擬した模型と光源（60 ワッ 卜電球 4 個), CCD カラービデオカメラ (SONY 社製), 画像処 理装置（PIAS 社製 LA-525 および NEC 製パソコン）で構成さ れている。光源とカメラは図 8(b)のように配置し,このユニッ 卜全体を水平軸から 65 度下向きに傾斜させて設置した。本実験 で用いた画像処理装置では，入力されたアナログ画像は $512 \times$ 512 画素に標本化され，おの抢のの画素に対して 256 階調に量子 化され, デジタル画像に変換される。

実験では現場を模擬した模型に複数の大岩を配置し, 前章で述 べた方法により大岩の検出を行った。配置する大岩の個数および 位置は乱数により 0 個から 6 個の間でランダムに決定した。なお 前章で述べた方法では，大岩同士が接触している場合はこれらの 分離ができず, 検出個数が不正確になる恐れがある。本実験では 後述するように大岩の検出個数で実験結果を評価するので, 簡単 のため大岩が互いに接触している場合は考慮せず，大岩は互いに 孤立して配置するようにした。なお，大岩同士の接触については 今後の検討課題としたい。また, 小割室は粉塵が多く舞うことか ら, 粉塵に対する処理法の安定性についても評価したが, 粉塵の 程度を定量的に評価・再現することが困難であった。そのため, ここでは粉塵がない状態で撮影された画像をプログラムで加工す ることにより, 粉塵の存在を模擬することにした。すなわち, 粉 塵が舞っている状態で撮影された画像中の画素の輝度值は, 粉塵 による光の乱反射のため粉塵がない状態での画素の輝度值より多 少高くなる。それゆえ, 粉塵のない状態を初めに撮影し, さらに 画像全体の 50 \% の画素にあたる 12,880 画素の X 座標拈よび $\mathrm{Y}$ 座標を乱数で決定し, 次式により粉塵が存在する状態での画像を 模擬的に求めた。

$$
P^{\prime}=\alpha \times P
$$

ここに, $P^{\prime}$ は粉塵の影響を受けた画素の輝度值であり， $P$ は粉 塵のない元の画素の輝度值である。また， $\alpha$ の值は予備実験で撮 影された画像を基に， $\alpha=1.1$ に決定した。

本実験では，ここで提案する大岩の自動検出システムの妥当性

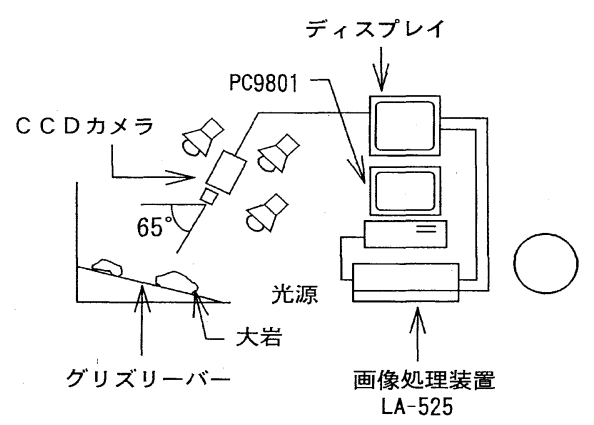

(a)

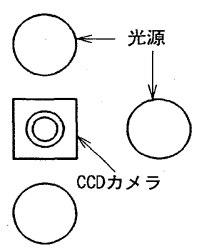

(b)
図 8 実験装置の概要
を評価するため, 次の 4 通りの条件について各 10 回の実験を行つ た。ただし, 実験 2 の方が実際の状態に近いので, 次章では実験 2 における結果のみを示すことにする。

·実験 1 グリズリーバー上に多数の小岩石が堆積していない状 態

\section{1)粉塵なし}

2)粉塵あり

・実験 2 グリズリーバー上に多数の小岩石が堆積している状態 1)粉塵なし

2)粉塵あり

\section{4. 実験結果および考察}

図 9(1)ないし図 9(9)に各画像処理後の結果を示した。まず, 図 9(1) および図 9(2)は 4 枚の原画像のうちの 1 つの原画像およ び重み付き 8 近傍フィル夕により雑音を除去した画像を示してい る。また, 図 9(3) 招よび図 9(4)は 2 值化後の画像拉よび 4 枚の 画像の合成後の画像を示している。図 9(4)をみると, 影により 大岩と他の小岩石がかなり分離されていることが分かる。本研究 では 2 值化後の画像の論理積をとって 1 枚の画像を作成し, その 画像を基に大岩の検出を行っているため, 大岩検出の成否に及ぼ す 2 值化処理の影響は極めて大きい。2 值化処理を行う際の最も 重要な点は, しきい值の設定であり, これについては(1)式で与 えることを既に述べた。図 9(1)に示される原画像全体の輝度の ヒストグラムを図 10 に示したが，このような双峰形の分布では， 一般に谷間に相当する輝度（ここでは約 120）をしきい值とする 方法がとられる。そこで，120をしきい值とした場合の 4 枚の合 成画像と, $32 \times 32$ の領域内の平均值 $\mathrm{m}$ をしきい值とした場合 の 4 枚の合成画像を図 11 に示した。図 11 と図 9(4) とを比較す ると, 平均值 $\mathrm{m}$ を用いた場合は, ほとんど大岩の検出が行われ てなく, またしきい值を 120 とした場合は, 右上の大岩の領域が 消滅していることが分かる。これに対し, しきい值として(1)式 を用いた場合は，大岩の領域がすべて残り，かつある程度背景と の分離が既に行われていることが分かる。図 10 のヒストグラム より, 88 という值は 2 つのピークの内, 輝度の小さい方のピー クに相当しており，この輝度の小さい方のピークに相当する輝度 を基準に，(1)式で与えられるしきい值を用いれば，なぜ大岩と 背景との分離がうまく行くのかは不明であるが，ここではサンプ リングされたすべての画像に対して，しきい值を(1)式で評価し た。なお，4枚の画像における黒の共通領域のみを残しているた め, 大岩領域は原画像の実際の大岩部分より多少小さくなること が何度か観察された。

図 9(5)に最小画素面積以下の領域, 壁および面積のしきい值 以下の領域を消去した結果を示した。さらに，残った領域で形状 係数が 6 以下の領域を検出し，これを検出結果として別のフレー ムメモリ（本画像処理装置では 4 枚のフレームメモリを有する） にコピーした後に消去すると図 9(6)(a)に示すような画像が得ら れる。図 9(6)(b)には図 9(5)より検出された大岩の領域が示され ている。

さて, 図 9(6)(a)より大岩に小岩石が融合し, その結果, 検出 されない大岩が存在することが分かる。そこで, 残された領域に ついて縮退処理を行うと，図 9(7)に示すような結果が得られる。 この画像に対し, 再び形状係数による判断を行うと大岩領域が検 出され，小岩石による領域が消去される。その後，縮退した回数 だけ膨張させると最終的に図 $9(8)$ に示すような画像が得られる。

図 9(9)に比較のため検出された大岩領域を原画像に重ね合わ せた結果を示した。なお，図中の黒点は計算された画像上に扔け 


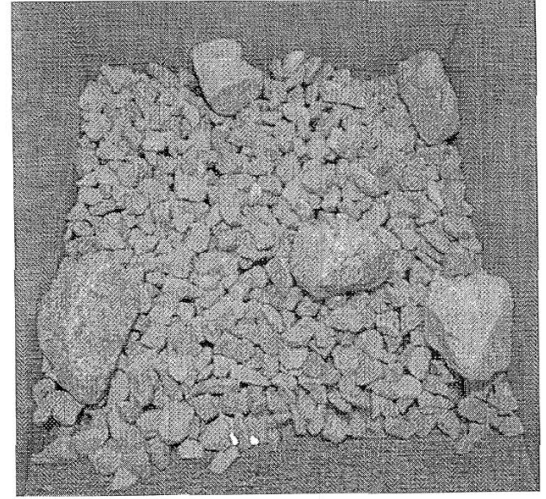

図 9 (1) 原画像の一例

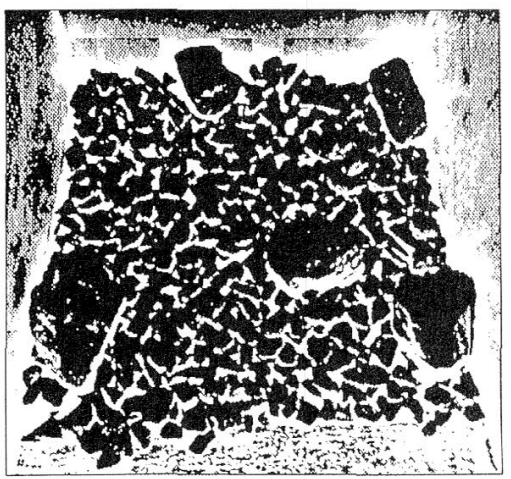

図 9 (3) 2 值化後の画像の一例

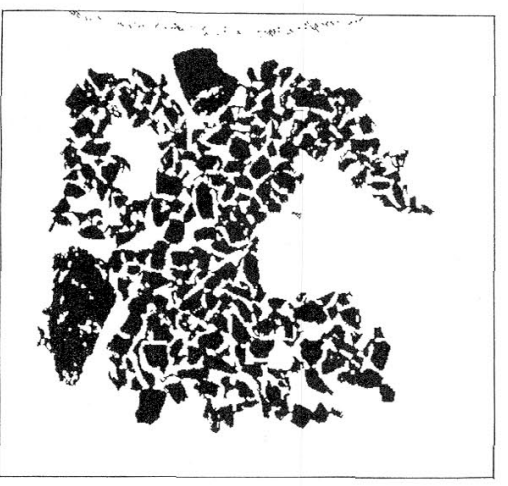

(a)大岩検出後の画像,

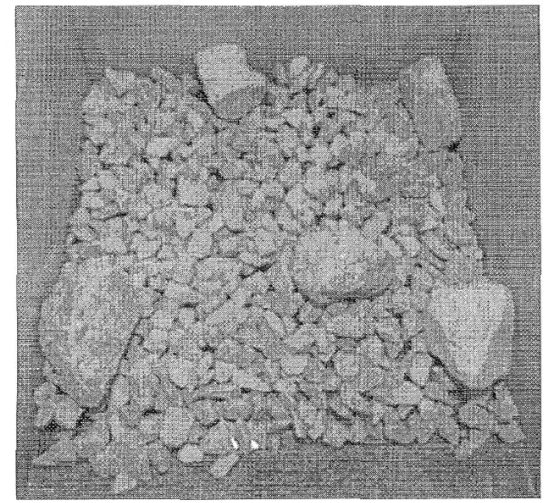

図 9(2) 杂隹音除去後の画像の一例

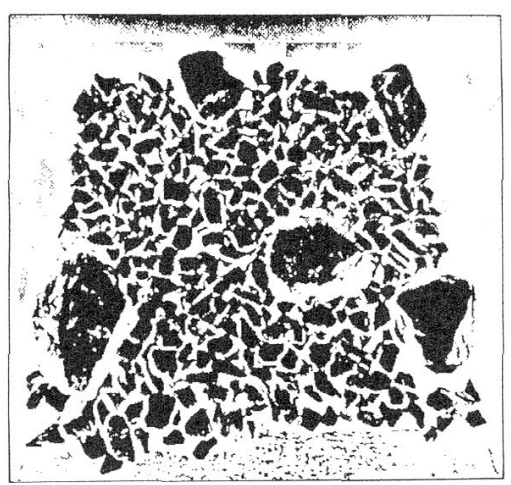

図 9 (4) 4 枚の論理積を求めた画像

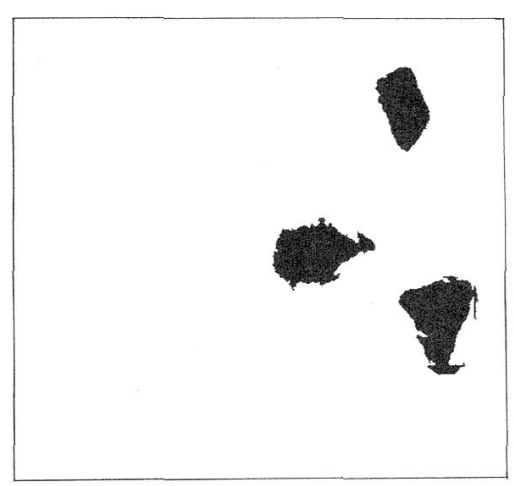

(b)検出された大岩領域

図 9 (6) 形状㩐数解析による結果

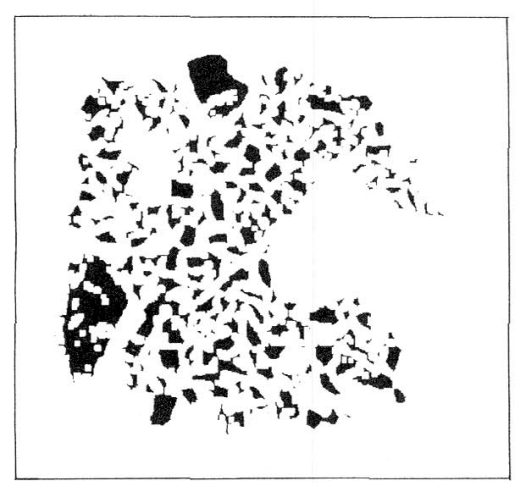

図 9 (7) 縮退処理後の画像

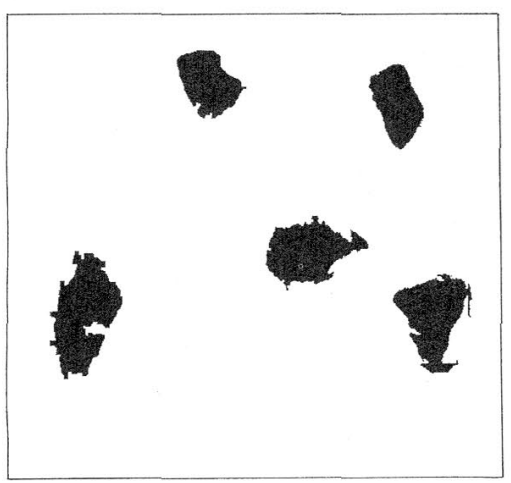

図 9（8）検出された大岩領域の最終結果

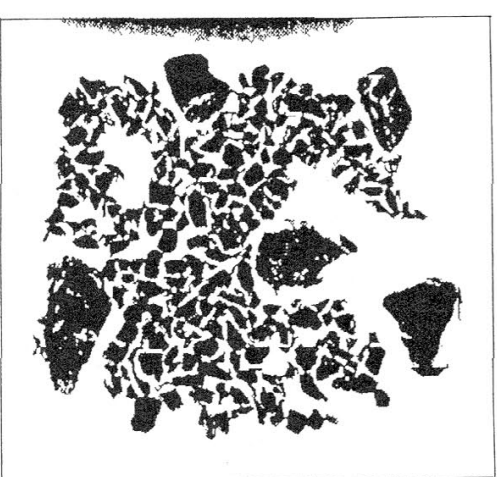

図 9 （5）最小画素面積以下の領域を消去した画像

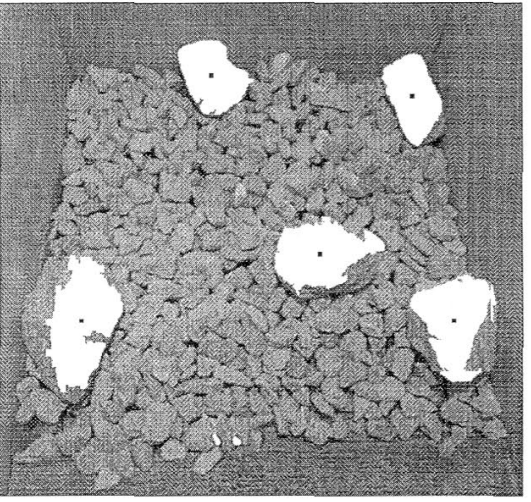

図 9（9）検出結果と原画像との比較 


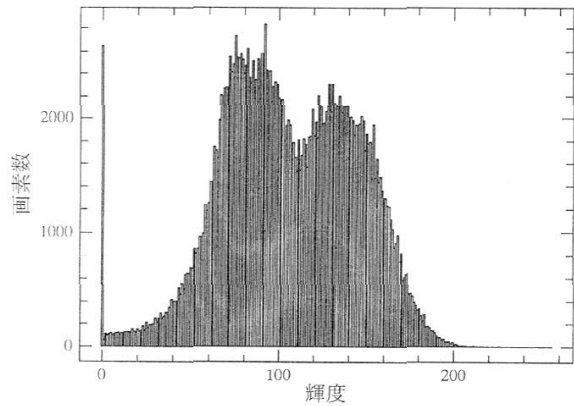

図 10 図9(1)に捛ける画像強度值のヒストグラん

る重心位置を示している。検出された領域は笑際の大岩よりも多 少小さくなっている。これは，処理の性質上，大岩の周囲全体を 縮退させるためであるが，検出された領域はおおむね大岩の領域 と一致している。

続いて大岩の検出能力について評価した。大岩の個数を 0 個か ら 6 個の範囲内でランダムに決定し，また大岩の位置も乱数によ り決定して合計 20 枚の画像老撮影し，さらにこれらの画像に粉 塵を加えた合計 40 枚の画像を用いて大岩の検出を行った。その 結果を表 1 に示した。画像中に扔忊る大岩の存在の有奥および検 出された大岩の個数について評価を行ったが, 設定した大岩の個 数だ画像処理法により大岩が検出された場合には成功例として カウントし, 画像処理の結果, 大岩が存在するという結果が得ら れても，検出された大岩の個数が設定した大岩の個数と異なる場 合は, エラーとした。表 1 に示されるように 4 つの条件で大岩の 検出性能に変化はないことが確かめられた。今回の実験では大岩 以外のものが大岩として検出されることはなかったが，大岩を検 出できないことが生じた。検出の失敗は図 12 のよう大岩表面 の凸凹に影が付き，領域の形状が不規則になり，その結果，検出 されず縮退され，領域が分断されたために検出されないものであっ た。

また，図 9(9)に示したように検出された大岩領域とその重心 を原画像に重放合わせて表示させた結果，検出された領域は抢掞 む称画像の大岩部分と一致した。また，大岩同士が重なり合って いない場合には，大岩の重心が原画像の大岩部分から外れること は40回の実験中 1 回も見られなかった。ただし，比較のため大 岩同士が重なり合った場合について大岩の検出を試みたが，大岩 同士が融合して検出され，検出された個数が実際の大岩の個数よ り少なくなり，かつ重心位置が大岩の部分から外れる場合が数回 見られた。大岩の重なりも実際の現場では観察される状態である ので，今後は大岩同士が重なり合った場合に扔ける処理法につい て検討する予定である。

なお，原画像の撮影から最終的に図 9(8)の結果を出力するま での処理時間は約 8 分であった。これは，平滑化処理と形状係数 の算出に比較的長時間を要するためであるが，より能力の高いコ ンピュー夕を使用し，かつこの処理の部分を回路化すれば，処理 時間は大幅に短縮できるものと思われる。

\section{5. むす び}

本研究では大岩の破砕作業の自動化を目指し，作業現場に扔け る岩石群の画像加大岩を検出し，その重心位置を求めるための 視覚情報処理法を提案し，その有効性について実験的に検討した。 本研究で提案した方法は，主として 2 值化という比較的簡単な処

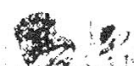
axis $\quad \therefore$ intos itos

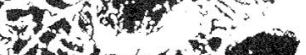
(1) 1 - 10 (a) a)しきい值：120

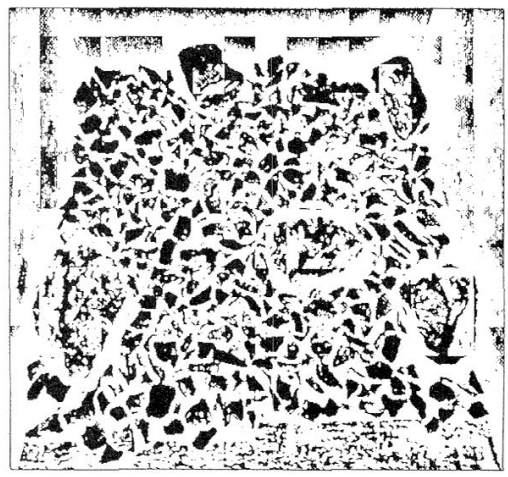

(b)しきい值： $32 \times 32$ 两素の領域に抢け 万画像強度值の平均值
図 114 枚の論理積を求めた画像

表 1 大岩の個数の検出に関する実験結果

\begin{tabular}{rll|l}
\hline 実験 $1(1)$ & 堆積なし & 粉塵なし & 10 回中 1 回エラー \\
\hline 実験 $1(2)$ & 堆積なし & 粉塵あり & 10 回中 1 回エラー \\
\hline 実験 $2(1)$ & 堆積あり & 粉塵なし & 10 回中 1 回エラー \\
\hline 実験 $2(2)$ & 堆積あり & 粉塵あり & 10 回中 1 回エラー \\
\hline
\end{tabular}
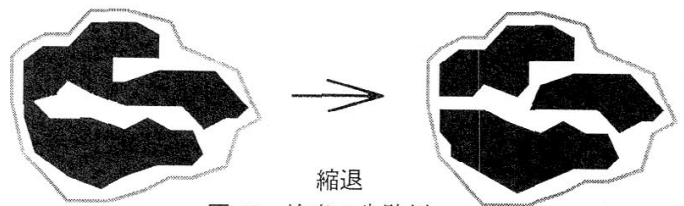

図 12 検出の失敗例

理方法を基にしているが，照明の工夫により大岩と小岩石による 背景をかなりの確率で分離できることが分かった。兴の結果，大 岩が重なり合っていない状態では比較的高精度で大岩を検出でき ることが確かめられた。これに対し, 本方法の久点としては暗い 色の岩石や，大岩表面の山凸が大きく影がつきや立い大岩は検出 が困難になることおよび重なり合った大岩を分離して検出できな いことが挙げられる。今後の課題としては, これらの欠点を解決 するとともに画像上の重心位置を実際の大岩表面の重心に変換す る手法の開発に努める予定である。

最後に, 本研究は(社) 東北建設協会「建設事業の技術開発に関 する助成金」掞上び石灰石鉱業協会研究奨励金によったことを付 記し，謝意を表する。また，石灰岩のサンプルを提供して頂いた 秋芳鉱業(株)にお礼申し上げる。

\section{引用文献}

1）伊藤博樹·高橋 弘. 益山忠: 資源と素材, Vol. 110, No. 6, p. 505-509, (1994)

2）高橋 弘·伊藤博樹·益山 忠: 資源と素材, Vol. 111, No. 2, p. 83-91, (1995)

3) Takahashi, H. et al. : Proc. of 3rd Int. Symposium on Mine Mechanization and Automation, Vol. 1, p. 33-44, (1995)

4）高橋 弘. 友成晃司 - 益山忠: 資源と素材, Vol. 111, No. 11, p. 767-773, (1995)

5）高橋 弘・小林喜代志・福山 忠：地下環境認識のための視覚情報処理，第２ 回建設ロボットシンポジウム論文集，p．71-76, (1991)

6) 中山智晴·今井啓太 : 石灰石, No. 271, p. 39-47, (1994)

7) 中山智晴. 今井啓太 : 石灰石, No. 272, p. 25-43, (1994)

8) 例えば, 舟久保 登: 視覚パ夕ーンの処理と認識, 啓学出版, p. $110-118$, (1990)

9）画像処理ハンドブック編集委員会編：画像処理ハンドブック，昭晃堂，p. 264 $314, \quad(1987)$

10）ピアス(株)：ピアス画像処理装置マニュアル 